\title{
Predictive value of social skills in living together at primary school. Analysis in a cultural diversity context
}

\author{
Lucía Herrera Torres ${ }^{1,}{ }^{*}$, Iván Bravo Antonio² \\ ${ }^{1}$ Facultad de Educación y Humanidades del Campus Universitario de Melilla, Universidad de Granada, \\ Spain \{luciaht@ugr.es\} \\ Equipo de Orientación Educativa y Psicopedagógica de la Ciudad Autónoma de Melilla, Melilla, Spain \\ \{ibravoantonio@yahoo.es\}
}

Received on 20 January 2012; revised on 8 February 2012; accepted on 25 February 2012; published on 15 July 2012

DOI: $10.7821 /$ naer.1.1.13-21

\begin{abstract}
Coexistence at school stands out as one of the main goals in today's education (Carretero, 2008; Ortega, 2007). The aim of this study developed within a cultural diversity context is to identify the specific dimensions of social skills through which the different elements favouring or hindering coexistence at school can be predicted. A total of 546 students $(52 \%$ of them males, and $48 \%$ females) from the first year in each Primary Education cycle $\left(1^{\text {st }}\right.$, $3^{\text {rd }}$ and $5^{\text {th }}$ year, respectively) of two public schools in Melilla took part in the research. The Behaviour Assessment System for Children (BASC) and an adapted version for Primary Education of the Coexistence at School Questionnaire for Students were the data-collection instruments used. According to the main results, while the clinical maladjustment dimension of BASC predicts negative coexistence situations, personal adjustment appears as the dimension which best predicts positive coexistence situations, conducting classroom behaviours (both anti-social and pro-social ones), as well as the implementation of conflict resolution strategies (both successful and failed ones). In this respect, self-esteem within the personal adjustment dimension plays an important role regarding coexistence at school. Both the need to develop preventive programmes at schools and the consideration of the different socio-familiar variables which may be mediating this process are discussed.
\end{abstract}

KEYWORDS: SOCIAL SKILLS, STUDENT SCHOOL RELATIONSHIP, PRIMARY EDUCATION, STUDENT DIVERSITY

\section{INTRODUCTION}

"And this is because there is no possibility of living without living together" (Jares, 2006, p. 11).

One of the aims of the education system nowadays is to achieve the full development of the personality and abilities of the students. Even though this implies working on their cognitive or intellectual development, it also means, in line with this integral vision of the human being, to enhance their emotional, motor, social and moral skills. In this sense, living together at school has become one of the main goals of education in order to promote the process by which all members of the school community learn to live with each other (Carretero, 2008). From this perspective, as expressed by Ortega (2007), coexisting or living together at school is to be understood, not merely as the absence of violence, but mainly as the establishment of satisfying interpersonal and group relations, an aspect that is intrinsically linked to that teaching and learning of social skills.
Although the various organic laws which have regulated the Spanish education system have echoed these concerns, it was not until the passage of the Organic Law on Education 2/2006 of May 3 (LOE) that a firm commitment on educating for a positive coexistence at school was made and, consequently, on the promotion and enhancement of the social competence of students. Previously the research and practical attention had been focused on the cognitive and intellectual aspects more closely related to academic success, leaving at the mercy of the teacher's discretion everything that had to do with the social and the personal competence of students, and with a learning content that was integrated into what is known as the hidden curriculum.

The LOE (2006) does indeed contain many references about living together at school, democratic citizenship and conflict resolution and prevention (Jares, 2006). In its Preamble it already mentions the practice of tolerance and freedom within the democratic principles of coexistence and conflict prevention and their peaceful resolution. It also highlights, in relation to the curriculum, the incorporation of the new subject Education for Citizenship and Human Rights. Additionally, the value of living together at school is collected not only among its main objectives and principles, but also through the specific objectives pursued, among other levels of education, in preschool education (Art. 13) and primary education (Art. 17).

As stated in Ramírez and Justicia (2006), the consideration of educational institutions as the places in which to teach young people to live together and thus to give them the necessary social skills to contribute to the the full process of their social and personal development is due, among other factors, to the increase in the amount of time that students must remain in the educational system as well as the higher professional qualifications of the educational community needs to make teaching and learning of social skills a real program of direct deliberate and systematic intervention (Jares, 2006; Ortega \& Del Rey, 2004).

Consequently, variables of a social nature are considered today one of the main determining factors of behavior or of the mode of action of individuals (Vázquez, Fariña, \& Seijo, 2003). In this regard, numerous studies highlight the importance of social skills in child development and their subsequent psychological, academic and social adjustment, (Delgado \& Contreras, 2008; Monjas, 2009; Seijo, Novo, Arce, Fariña, \& Mesa, 2005). If we take these views into account, it should be noted that if the goal of education is to promote the integral 
development of students, it is necessary to take into account within the school environment the area of interpersonal competences and the teaching and formation of social skills through their inclusion in the curriculum (Monjas \& González, 2000), which, as has been claimed by several authors, is a clear indicator of the school life quality and of the prevention of violence and any other disruptive events that could affect it (Beck \& Forehand, 1984; Caballo, 1993, Gresham, 1988).

Therefore, a positive climate of coexistence depends as in every complex reality on a large number of factors, but especially on those including those that have a remarkable influence on the development of the social and emotional skills of our students (Campo, Fernández, \& Grisañela, 2005; Creemers \& Reezigt, 1999; Freiberg, 1999), especially considering that educating on interpersonal relationships from the earliest years of schooling has the advantage of preventing the development of problems that may occur later, at the end of primary education or during compulsory secondary school. In this sense, improving social competence and interpersonal relationships as part of the curriculum of educational institutions is conceived as a prevention measure with a triple effect (Monjas, 2009):

a) on individual risks associated with antisocial behavior and social and school maladjustment,

b) on the risk of school violence episodes, prevalence of unruly behavior, fighting, bad relationships and aggression in the school centre,

a) on the social problems associated with conflicts of violence, racism, intolerance and rejection of certain people.

Given the complexity of variables involved in the school context as described above and with the influence of the great social and family changes that characterize today's society (Rodríguez, Herrera, Lorenzo, \& Álvarez, 2008), it is increasingly likely to see conflicts in the classroom that might trigger violence behaviour (Benbenishty \& Astor, 2008; Calvo, 2003; Peralta, 2004). This phenomenon, despite the differences in the structure and organization of the education systems around the world (UNESCO, 2004), has become a global phenomenon that affects most countries (Akiba, 2004; Furlong, Grief, Bates, Whipple, Jiménez, \& Morrison, 2005; Herrera, Ortiz, \& Sánchez, 2010; Smith, 2003).

This is why so many programs have arisen with a focus on improving social competence. These programs are having a positive impact in the creation of an adequate environment that enables living together at school, and have threfore been used in Spanish education centres (Díaz-Aguado, 2002, 2005; Domingo, 2008; Fernández, Pichardo, \& Arco, 2005; Goldstein, Sprafkin, Gershaw, \& Klein, 1989; Hirchstein, Edstrom, Frey, Snell, \& McKenzie, 2007; Johnson, Johnson, \& Smith, 1998; Michelson, Sugai, Wood, \& Kazdin, 1987; Monjas, 1993; Trianes, 1996; Verdugo, 1997).

Taking into account what has been described so far, the main objective of this study is to identify, in a context of cultural diversity, which dimensions of social skills predict the different aspects that facilitate or hinder living together in primary school classrooms.

\section{METHOD}

\subsection{Participants}

Before describing the participants, it may be useful to situate the autonomous city of Melilla, where this study was developed, in its geographical, social and cultural context. With an area of $12.3 \mathrm{~km}^{2}$, it is located on the north coast of Africa, in the eastern part of the Cape Three Forks. By sea, it has $9 \mathrm{~km}$ of coastline and it is $180 \mathrm{~km}$ away from the city of Almería and $210 \mathrm{~km}$ from Malaga. The closest Spanish territory by land is the Autonomous City of Ceuta, $452 \mathrm{~km}$ away from Melilla. It shares with Morocco, its neighboring country, about $11 \mathrm{~km}$ of linear boundaries that form the outer border to the south of the European Union, which is crossed by thousands of people daily (Laureano, 2002).

The geographic location of the city, west of the Greenwich Meridian, and on the northern coast of Africa, offers a warm Mediterranean climate $\left(19^{\circ} \mathrm{C}\right.$ on average and more than 2,522 hours of sunshine a year), with mild winters and hot summers, little rainfall and the relative humidity is around $70 \%$ (Mayoral, 2005).

Melilla has a population of 73,460 inhabitants, due mainly to the natural growth of the city, a mortality rate that is lower than in mainland Spain, a birth rate which is almost doubles the national average and a population density that exceeds the Spanish and the European Union average (Instituto Nacional de Estadística, 2010).

According to data provided by the report on the status and situation of the educational system of the Consejo Escolar del Estado (2010), 43\% of its population is of Spanish origin, Spanish speakers and of Christian religion, followed by a $48 \%$ of Berber origin, mainly Muslims native to the area of the Rif, whose native language is Tamazight, the Berber language of the ancient inhabitants of North Africa which has no common roots with the Arabic language or its dialects (Herrera, Defior \& Lorenzo, 2007; Tilmatine, El Molghy, Castellanos, \& Banhakeia, 1998). Besides these two larger cultures there is also a Jewish community, mostly Sephardi, and a small representation of the Hindu community. The multicultural richness of the city's daily life is its main landmark, and its economy is based almost exclusively on administrative, commercial and catering services, which account for $90 \%$ of the total employment (López-Guzmán, González, Herrera, \& Lorenzo, 2007).

A total of 546 students were involved in this study (52\% male and $48 \%$ female) of the first course of each primary education cycle: 137 first year students (25.1\%), 204 third year students (37.4\%) and 205 fifth year students (37.5\%). The students came from two public schools in the autonomous city of Melilla (64.3\% of students in school 1 and $35.7 \%$ of the in school 2$)$. The distribution of students in each school, depending on the course, is shown in Table 1. 
Table 1. Distribution of participants according to the school they belong to and the course they are in

\begin{tabular}{lllllll}
\hline & \multicolumn{2}{l}{ School } & & & & \\
\multirow{2}{*}{ Year } & \multicolumn{2}{l}{ School 1 } & \multicolumn{3}{l}{ School 2 } & Total \\
\cline { 2 - 5 } & $\boldsymbol{N}$ & $\mathbf{\%}$ & $\boldsymbol{N}$ & $\mathbf{\%}$ & $\boldsymbol{N}$ & $\mathbf{\%}$ \\
\hline $1^{\text {st }}$ & 101 & $28.8 \%$ & 36 & $18.5 \%$ & 137 & $25.1 \%$ \\
$3^{\text {rd }}$ & 127 & $36.2 \%$ & 77 & $39.5 \%$ & 204 & $37.4 \%$ \\
$5^{\text {th }}$ & 123 & $35.0 \%$ & 82 & $42.1 \%$ & 205 & $37.5 \%$ \\
Total & 351 & $100 \%$ & 195 & $100 \%$ & 546 & $100 \%$ \\
\hline
\end{tabular}

\subsection{Tools}

We used two data collection tools which we proceed to describe below:

- Behavior Assessment System for Children (BASC) by Reynolds and Kamphaus (1992), which was adapted to the Spanish population by González, Fernández, Pérez, and Santamaría (2004). An S scale was used (self-reported) and the level 2 (subjects aged 6-11 years), consisting of 146 items. This instrument assesses four dimensions: clinical maladjustment (anxiety, atypicality, locus of control); school maladjustment (negative attitude towards school, negative attitude towards teachers); personal adjustment (interpersonal relations, relationship with parents, selfconfidence, self-esteem); and index of emotional symptoms (anxiety, interpersonal relations, self-esteem, social stress, depression, sense of inadequacy). Furthermore, the psychometric properties of reliability (over .70) and validity are met.

- An adapted version for Primary School of the Living Together at School Questionnaire for Students (Cuestionario sobre Convivencia Escolar para Alumnos) by Sánchez et al. (2009). In the adaptation the language was revised and adjusted to a Primary Education level. In turn, we established the following categories within the questionnaire:

- People of support in the centre, i.e., friends, both in the centre and in the classroom, with the following response options: none, one, two, three, four or five, and more than five.

- Respect towards school equipment and facilities, which could be positive (school supplies are treated with care, centre facilities are respected, etc.) or negative (painting tables and walls, breaking school supplies, littering the ground, etc.). A Likert type scale was used, with four response options to choose from: Never, Sometimes, Often, Always.

- Living together situations, which could be positive (obeying the teacher, meeting the school rules of conduct, paying attention to teachers during explanations, etc.) and negative (provoking or insulting the teachers, coming in and out of class without permission, apathic behaviors, etc.). Students should answer the following items in this category following the same scale as the one indicated in the previous category.

- Relations between members of the educational community (among students, among teachers, among parents, among parents and teachers, etc.). The response options to describe these relationships were: Very poor, Poor, Good, Very good.
- The student as a recipient, an actor and an observer of behaviors (prosocial and of abuse or bullying), differentiating between the type of behavior (positive and negative), the location (inside or outside the school) and the background of the offender or victim (student or nonstudent).

- Coping strategies (positive and negative). The students had to respond on a scale indicating one of the four options previously mentioned: Never, Sometimes, Often, Always. The response scale used in the following categories (except in the last one) was the same.

- People of support people when facing personal problems (nobody, peers and adults).

- School life conflict resolution (positive and negative).

- Class participation (positive and negative).

- Information about living together at school.

- Training on living together at school, where they had to specify their interest in such training (yes or no), how they would like to learn it (as if it were another subject or as an extracurricular activity) and who should be responsible for the training (the teachers at the school, outside-school professionals specialized in school life and coexistence, teachers at the school and external professionals together or teachers and parents together).

The reliability of this second instrument is .925 , measured through the internal coefficient of consistency Cronbach's alpha. In order to adapt the original version, we validated its content using expert opinion.

\subsection{Procedure}

For the administration of both instruments all the prerequisites were met: informing the management teams of the schools, submitting the research project to the Comisión de Investigación de la Facultad de Educación y Humanidades de Melilla, and getting an approval by the provincial ministry of education in Melilla, complying in all cases with the standards of student anonymity.

The use of the Behavior Assessment System for Children (BASC) took place during the second term of the 2009-2010 school year. The tutors were responsible for its distribution and there was a preparatory session in advance. For its part, the adapted version of the Living Together at School Questionnaire for Students was administered during the third term. As in the previous case, on this occasion the tutors were also in charge of assessing the students.

Once the data was collected, the information was introduced into the statistical program PASW Statistics 18.0 and we proceeded to analyze it.

\section{RESULTS}

\subsection{Results obtained through the Behavior Assessment System for Children (BASC, 2004)}

Table 2 shows the descriptive analysis of the scores, expressed in percentiles for each of the four global dimensions that are part of the S2 scale of the BASC. 
Table 2. Descriptive statistics of the overall size of the BASC

\begin{tabular}{llll}
\hline DIMENSIONS (PERCENTILES) & $\boldsymbol{N}$ & $\boldsymbol{M}$ & $\boldsymbol{S D}$ \\
\hline Clinical Maladjustment & 355 & 60.67 & 28.11 \\
School Maladjustment & 393 & 68.90 & 27.19 \\
Personal Adjustment & 407 & 33.88 & 23.21 \\
Emotional Symptoms Index & 339 & 63.08 & 21.66
\end{tabular}

The highest average scores appear in the School maladjustment dimension (68.90) followed by the Index of emotional symptoms (63.08), Clinical maladjustment (60.67) and Personal Adjustment (33.88).

Table 3 presents the scores, expressed in percentiles, for each of the factors that make up the scale S2 of the BASC.

Table 3. Descriptive statistics of the BASC factors

\begin{tabular}{llll}
\hline FACTORS (PERCENTILES) & $\boldsymbol{N}$ & $\boldsymbol{M}$ & $\boldsymbol{S D}$ \\
\hline Negative attitude towards school & 401 & 67.51 & 23.22 \\
Anxiety & 389 & 49.10 & 29.35 \\
Negative attitude towards teachers & 411 & 64.27 & 24.79 \\
Atypicality & 399 & 61.09 & 28.87 \\
Self-Esteem & 407 & 41.40 & 24.95 \\
Self-Confidence & 401 & 38.14 & 26.39 \\
Depression & 396 & 66.94 & 26.88 \\
Social stress & 402 & 63.26 & 24.96 \\
Locus of control & 389 & 68.20 & 23.72 \\
Interpersonal Relations & 410 & 33.33 & 25.71 \\
Relationship with parents & 399 & 44.12 & 27.66 \\
Sense of inadequacy & 403 & 64.91 & 26.65 \\
\hline
\end{tabular}

As shown in the table above, the average value for each of the 12 factors that make up the S2 scale of the BASC oscillates between 33.33 and 68.20 .

\subsection{Results obtained from the adapted version of the Living Together at School Questionnaire for Students}

The table below shows the resulting descriptive statistics for each of the categories, dimensions and aspects of the questionnaire (see Table 4).

Table 4. Descriptive statistics of the categories, dimensions and aspects of the adapted version of the Living Together at School Questionnaire for Students

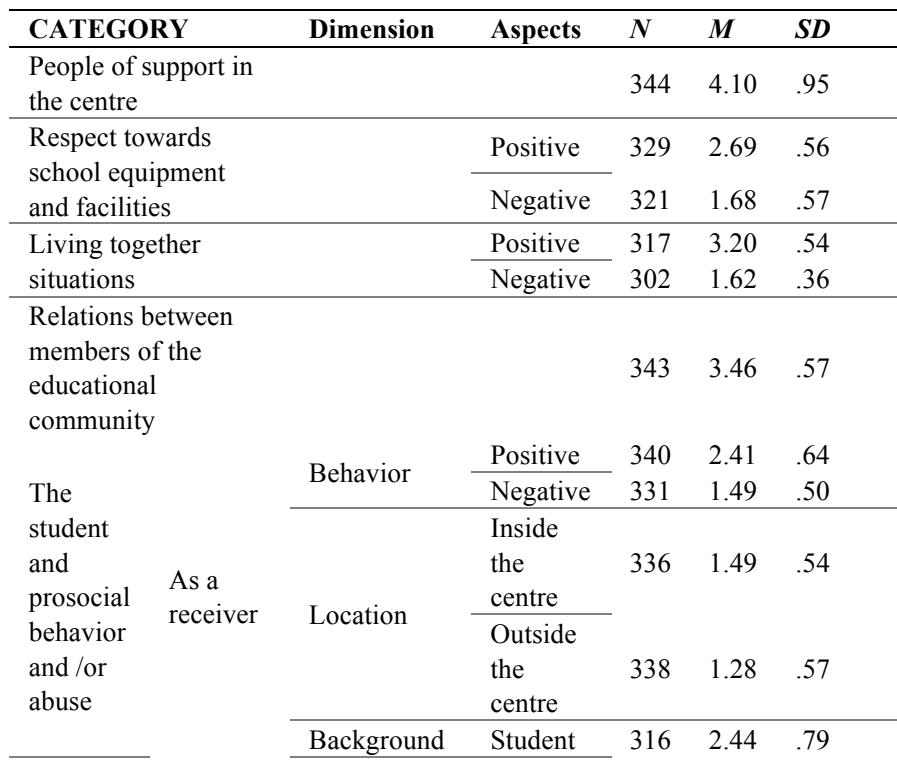

\begin{tabular}{|c|c|c|c|c|c|}
\hline \multirow{7}{*}{$\begin{array}{l}\text { As an } \\
\text { actor }\end{array}$} & Dimension & Aspects & $N$ & $M$ & $S D$ \\
\hline & $\begin{array}{l}\text { of the } \\
\text { aggressor }\end{array}$ & $\begin{array}{l}\text { Non- } \\
\text { student }\end{array}$ & 328 & 1.62 & .52 \\
\hline & \multirow{2}{*}{ Behavior } & Positive & 323 & 1.61 & .64 \\
\hline & & Negative & 340 & 1.42 & .70 \\
\hline & Location & $\begin{array}{l}\text { Inside } \\
\text { the } \\
\text { centre } \\
\text { Outside } \\
\text { the } \\
\text { centre }\end{array}$ & 343 & 2.47 & .75 \\
\hline & \multirow{2}{*}{$\begin{array}{l}\text { Background } \\
\text { of the victim }\end{array}$} & Student & 338 & 1.33 & .60 \\
\hline & & $\begin{array}{l}\text { Non- } \\
\text { student }\end{array}$ & 340 & 1.27 & .60 \\
\hline \multirow{6}{*}{$\begin{array}{l}\text { As an } \\
\text { observer }\end{array}$} & \multirow{2}{*}{ Behavior } & Positive & 333 & 1.42 & .66 \\
\hline & & Negative & 339 & 1.35 & .72 \\
\hline & \multirow{2}{*}{ Location } & $\begin{array}{l}\text { Inside } \\
\text { the } \\
\text { centre }\end{array}$ & 332 & 2.48 & .79 \\
\hline & & $\begin{array}{l}\text { Outside } \\
\text { the } \\
\text { centre }\end{array}$ & 331 & 1.50 & .63 \\
\hline & \multirow{2}{*}{$\begin{array}{l}\text { Background } \\
\text { of the } \\
\text { aggressor }\end{array}$} & Student & 337 & 1.62 & .68 \\
\hline & & $\begin{array}{l}\text { Non- } \\
\text { student }\end{array}$ & 337 & 1.42 & .71 \\
\hline \multirow{2}{*}{ Coping strategies } & & Positive & 336 & 1.61 & .68 \\
\hline & & Negative & 343 & 1.43 & .70 \\
\hline \multirow{3}{*}{$\begin{array}{l}\text { People of support } \\
\text { people when facing } \\
\text { personal problems }\end{array}$} & Nobody & & 344 & 1.61 & 1.05 \\
\hline & Peer & & 337 & 1.89 & .83 \\
\hline & Adults & & 326 & 1.94 & .92 \\
\hline \multirow{2}{*}{$\begin{array}{l}\text { School life conflict } \\
\text { resolution }\end{array}$} & & Positive & 332 & 2.42 & .90 \\
\hline & & Negative & 337 & 1.90 & .64 \\
\hline \multirow{2}{*}{ Class participation } & & Positive & 343 & 2.17 & .62 \\
\hline & & Negative & 343 & 1.50 & .57 \\
\hline $\begin{array}{l}\text { Information about } \\
\text { living together at } \\
\text { school. }\end{array}$ & & & 344 & 3.01 & .93 \\
\hline \multirow{3}{*}{$\begin{array}{l}\text { Training on living } \\
\text { together at school }\end{array}$} & Interest & & 344 & .91 & .27 \\
\hline & Learning & & 315 & 1.38 & .48 \\
\hline & Educator & & 315 & 2.23 & 1.29 \\
\hline
\end{tabular}

The main results found show that students have around 4-5 friends in the centre or in the classroom; respect towards the material and the school facilities is not very high but disrespect to them tends to be low; positive living together situations at school are frequent, and the negative are scarce; that relations between members of the school community are, in general, valued by students as good; although the positive and negative behaviors in which students participate as receptors, actors or observers are not frequent, the most frequent situation is the prosocial behavior, and the place in which all these conducts take place is inside the centre among students; coping strategies (positive and negative) are not routinely used by students; when in trouble they usually look for support in an adult; conflicts in the centre are resolved in a positive way rather than negatively, although not frequently; class participation isn't normally high; students indicate having received enough information about living together at school; regarding the training on school life, most are interested in receiving it, mainly as another subject taught by a teacher or both by teachers and parents together.

\subsection{Results of the predictive analysis}

In this section we will analyze the predictive value that each of the four global dimensions of the BASC have in relation to the adaptation categories of the Living Together at School 
Questionnaire for Students that relate more directly to the student as an actor and the climate of living together at school. In order to do this, we firstly conducted an analysis of linear regression in which the predictor variables were the percentiles in the four BASC dimensions: clinical maladjustment, school maladjustment, personal adjustment and index of emotional symptoms, and the dependent variable was the category Living together situations-positive (see Table 5).

Table 5. Linear regression analysis in which the predictor variables are the global dimensions of the BASC (percentiles) and the dependent variable is the category Living together situations-positive of the adaptation of the Living Together at School Questionnaire for Students

\begin{tabular}{|c|c|c|c|c|c|}
\hline \multirow[b]{2}{*}{ DIMENSIONS $(P)^{2}$} & \multicolumn{2}{|c|}{$\begin{array}{l}\text { Unstandardized } \\
\text { coefficients }\end{array}$} & \multicolumn{3}{|c|}{$\begin{array}{l}\text { Standardized } \\
\text { coefficients }\end{array}$} \\
\hline & B & $E r r^{I}$ & $\beta$ & $t$ & $p$ \\
\hline (Constant) & 3.376 & .198 & & 17.047 & $.000 * *$ \\
\hline $\begin{array}{l}\text { Clinical } \\
\text { Maladjustment }\end{array}$ & .003 & .003 & .149 & 1.047 & .297 \\
\hline $\begin{array}{l}\text { School } \\
\text { Maladjustment }\end{array}$ & -.002 & .002 & -.079 & -.837 & .404 \\
\hline $\begin{array}{l}\text { Personal } \\
\text { Adjustment }\end{array}$ & .006 & .002 & .247 & 2.523 & $.013^{*}$ \\
\hline $\begin{array}{l}\text { Emotional } \\
\text { Symptoms Index }\end{array}$ & -.006 & .004 & -.234 & -1.719 & .088 \\
\hline
\end{tabular}

${ }^{1}$ Typ. Error.; ${ }^{1}$ Percentiles.; ${ }^{* *} p<.001 ;{ }^{*} p<.05$

Since the Personal adjustment dimension was predicted by Positive living together situations $[t=2.523 ; p<.05]$, we performed a second linear regression analysis to determine which factor or factors of that dimension were specifically the ones directly involved in predicting this category, which is shown in Table 6.

Table 6. Linear regression analysis in which the predictors are the different factors that make up the global dimension Personal adjustment of the BASC (percentiles) and the dependent variable is the category Living together situations-positive of the adapted version of the Living Together at School Questionnaire for Students

\begin{tabular}{llllll}
\hline & \multicolumn{4}{l}{$\begin{array}{l}\text { Unstandardized } \\
\text { coefficients }\end{array}$} & $\begin{array}{l}\text { Standardized } \\
\text { coefficients }\end{array}$ \\
\cline { 2 - 7 } FACTORS $(P)^{2}$ & $\boldsymbol{B}$ & $\boldsymbol{E} \boldsymbol{r} \boldsymbol{r}^{I}$ & $\boldsymbol{\beta}$ & $\boldsymbol{t}$ & $\boldsymbol{p}$ \\
\hline (Constant) & 2.857 & .099 & & 28.972 & $.000^{* *}$ \\
Self-Esteem & .004 & .002 & .191 & 2.366 & $.019^{*}$ \\
Self-Confidence & .003 & .002 & .172 & 2.124 & $.035^{*}$ \\
Interpersonal & .002 & .002 & .069 & .857 & .393 \\
$\begin{array}{l}\text { Relations } \\
\text { Relationship with }\end{array}$ & .000 & .002 & .007 & .089 & .929 \\
Parents & .007 & & & & \\
\hline
\end{tabular}

${ }^{1}$ Typ. Error.; ${ }^{1}$ Percentiles.; ${ }^{* *} p<.001 ; * p<.05$

Both the Self-Confidence factor $[t=2.124, p<.05]$ and the Self-Esteem $[t=2.366 ; p<.05]$ factor predicted Positive living together situations.

The same type of analysis was carried out but, in this case, to determine the predictive value of the four dimensions regarding the Living together situations-negative (see Table 7).
Table 7. Linear regression analysis in which the predictor variables are the global dimensions of the BASC (percentiles) and the dependent variable is the category of Living together situations-negative of the adapted version of the Living Together at School Questionnaire for Students

\begin{tabular}{llllll}
\hline & \multicolumn{4}{l}{$\begin{array}{l}\text { Unstandardized } \\
\text { coefficients }\end{array}$} & \multicolumn{2}{l}{$\begin{array}{l}\text { Standardized } \\
\text { coefficients }\end{array}$} \\
\cline { 2 - 6 } DIMENSIONS $(P)^{2}$ & $\mathbf{B}$ & $\boldsymbol{E} \boldsymbol{r r}^{I}$ & $\boldsymbol{\beta}$ & $\boldsymbol{t}$ & $\boldsymbol{p}$ \\
\hline (Constant) & 1.509 & .124 & & 12.207 & $.000^{* *}$ \\
Clinical & .005 & .002 & .439 & 3.136 & $.002^{* *}$ \\
$\begin{array}{l}\text { Maladjustment } \\
\text { School }\end{array}$ & -.001 & .001 & -.060 & -.648 & .518 \\
$\begin{array}{l}\text { Maladjustment } \\
\text { Personal Adjustment }\end{array}$ & -.002 & .001 & -.137 & -1.401 & .164 \\
$\begin{array}{l}\text { Emotional } \\
\text { Symptoms Index }\end{array}$ & -.001 & .002 & -.061 & -.459 & .647 \\
\hline
\end{tabular}

${ }^{1}$ Typ. Error.; ${ }^{1}$ Percentiles.; ${ }^{* *} p<.001 ;{ }^{*} p<.05$; Dependent variable: Living together situations-negative

In this case, the dimension Clinical Maladjustment predicted the category Negative living togehter situations $[t=3.136, p<$. $01]$. We proceeded to perform a linear regression analysis to determine which factor or factors within the Clinical Maladjustment dimension were responsible for this category (see Table 8).

Table 8. Linear regression analysis in which the predictors are the different factors that make up the global dimension Clinical Maladjustment of the BASC (percentiles) and the dependent variable is the category Living together situations-negative of the adaptation of the Living Together at School Questionnaire for Students

\begin{tabular}{llllll}
\hline & \multicolumn{2}{l}{$\begin{array}{l}\text { Unstandardized } \\
\text { coefficients }\end{array}$} & \multicolumn{2}{l}{$\begin{array}{l}\text { Standardized } \\
\text { coefficients }\end{array}$} \\
\cline { 2 - 6 } FACTORS $(P)^{2}$ & $\mathbf{B}$ & $\boldsymbol{E r r}^{\boldsymbol{I}}$ & $\boldsymbol{\beta}$ & $\boldsymbol{t}$ & $\boldsymbol{p}$ \\
\hline (Constant) & 1.289 & .081 & & 15.877 & $.000^{* *}$ \\
Anxiety & .002 & .001 & .139 & 1.470 & .144 \\
Atypicality & .002 & .001 & .167 & 1.702 & .091 \\
Locus of Control & .002 & .001 & .141 & 1.550 & .123 \\
\hline
\end{tabular}

${ }^{1}$ Typ. Error.; ${ }^{1}$ Percentiles.; ${ }^{* *} p<.001 ;{ }^{*} p<.05$; Dependent variable: Living together situations-negative

With a borderline significance, it was the Atypicality factor that predicted the Negative living together situations $[t=1.702$; $p=.09]$.

Table 9 shows the results obtained after performing a linear regression analysis in which each of the global dimensions (percentiles) that are part of the BASC acted as predictor variables and the dependent variable was the category The student as an actor of antisocial and/or prosocial behaviorpositive. 
Table 9. Linear regression analysis in which the predictor variables are the global dimensions of the BASC (percentiles) and the dependent variable is the category The student as an actor of prosocial behavior of the adaptation of the Living Together at School Questionnaire for Students

\begin{tabular}{llllll}
\hline & \multicolumn{2}{l}{$\begin{array}{l}\text { Unstandardized } \\
\text { coefficients }\end{array}$} & \multicolumn{2}{l}{$\begin{array}{l}\text { Standardized } \\
\text { coefficients }\end{array}$} \\
\cline { 2 - 6 } DIMENSIONS $(P)^{2}$ & $\mathbf{B}$ & $\boldsymbol{E r r}^{\boldsymbol{I}}$ & $\boldsymbol{\beta}$ & $\boldsymbol{t}$ & $\boldsymbol{p}$ \\
\hline (Constant) & 2.343 & .252 & & 9.304 & $.000^{* *}$ \\
$\begin{array}{l}\text { Clinical } \\
\text { Maladjustment }\end{array}$ & .005 & .004 & .197 & 1.444 & .151 \\
$\begin{array}{l}\text { School } \\
\text { Maladjustment }\end{array}$ & -.001 & .002 & -.047 & -.525 & .600 \\
$\begin{array}{l}\text { Personal Adjustment } \\
\text { Emotional }\end{array}$ & .009 & .003 & .314 & 3.327 & $.001 * *$ \\
Symptoms Index & -.006 & .005 & -.178 & -1.378 & .170 \\
\hline
\end{tabular}

${ }^{1}$ Typ. Error.; ${ }^{1}$ Percentiles.; ${ }^{* *} p<.001 ; * p<.05$; Dependent variable: The student as an actor of prosocial behaviour

The dimension Personal adjustment is the only variable that predicts the emission of positive behavior by students $[t=3.327$; $p<.01]$. In order to determine which factor or factors in that dimension are responsible for this category, we proceeded to conduct a second linear regression analysis (see table 10).

Table 10. Linear regression analysis in which the predictor variables are the different factors that make up the global dimension Personal adjustment of the BASC (percentiles) and the dependent variable is the dimension of the adaptation of the Living Together at School Questionnaire for Students which evaluates the positive aspects of the category The student as an actor of antisocial and/or prosocial behaviour.

\begin{tabular}{llllll}
\hline & \multicolumn{2}{l}{$\begin{array}{l}\text { Unstandardized } \\
\text { coefficients }\end{array}$} & \multicolumn{4}{l}{$\begin{array}{l}\text { Standardized } \\
\text { coefficients }\end{array}$} \\
\cline { 2 - 6 } FACTORS $(P)^{2}$ & $\mathbf{B}$ & $\boldsymbol{E r r}^{I}$ & $\boldsymbol{\beta}$ & $\boldsymbol{t}$ & $\boldsymbol{p}$ \\
\hline $\begin{array}{l}\text { (Constant) } \\
\text { Self-Esteem }\end{array}$ & .001 & .124 & & 16.824 & $.000^{*}$ \\
$\begin{array}{l}\text { Self-Confidence } \\
\begin{array}{l}\text { Interpersonal } \\
\text { Relations }\end{array}\end{array}$ & .007 & .002 & .021 & .266 & .791 \\
$\begin{array}{l}\text { Relations with } \\
\text { Parents }\end{array}$ & $9.21 \mathrm{E}-005$ & .002 & .270 & 3.545 & $.000^{*}$ \\
\hline
\end{tabular}

${ }^{1}$ Typ. Error.; ${ }^{1}$ Percentiles.; Dependent variable: The student as an actor of prosocial behavior

Based on the information in the table above we can conclude that the Self-Confidence factor is the one that best predicts positive student behavior $[t=3.545 ; p<.001]$.

Now we will proceed to explain the analysis carried out to determine the predictive value of the four global dimensions of the BASC regarding the dimension which evaluates the negative aspects of the category The student as an actor of antisocial and/or prosocial behavior (see Table 11).
Table 11. Linear regression analysis in which the predictor variables are the global dimensions of the BASC (percentiles) and the dependent variableis the category of the student as an actor of antisocial behavior of the adaptation of the Living Together at School Questionnaire for Students

\begin{tabular}{|c|c|c|c|c|c|}
\hline \multirow[b]{2}{*}{ DIMENSIONS $(P)^{2}$} & \multicolumn{2}{|c|}{$\begin{array}{l}\text { Unstandardized } \\
\text { coefficients }\end{array}$} & \multicolumn{2}{|c|}{$\begin{array}{l}\begin{array}{l}\text { Standardized } \\
\text { coefficients }\end{array} \\
\end{array}$} & \multirow[b]{2}{*}{$p$} \\
\hline & B & $E r r^{I}$ & $\beta$ & $t$ & \\
\hline (Constant) & 1.133 & .133 & & 8.520 & $.000^{* *}$ \\
\hline $\begin{array}{l}\text { Clinical } \\
\text { Maladjustment }\end{array}$ & .001 & .002 & .069 & .512 & .609 \\
\hline $\begin{array}{l}\text { School } \\
\text { Maladjustment }\end{array}$ & .000 & .001 & -.012 & -.140 & .889 \\
\hline $\begin{array}{l}\text { Personal } \\
\text { Adjustment }\end{array}$ & -.004 & .001 & -.256 & -2.742 & $.007^{*}$ \\
\hline $\begin{array}{l}\text { Emotional } \\
\text { Symptoms Index }\end{array}$ & .003 & .002 & .163 & 1.286 & .200 \\
\hline
\end{tabular}

${ }^{1}$ Typ. Error.; ${ }^{1}$ Percentiles.; $* * p<.001 ;{ }^{*} p<.05$; Dependent variable: The student as an actor of antisocial behavior

From the results obtained it can be noted that the Personal Adjustment dimension is the only variable that predicts the negative behaviors of the students $[t=-2.742 ; p<.01]$. In order to confirm which factor or factors of this dimension were responsible in this category, we performed a second linear regression analysis (see Table 12).

Table 12. Linear regression analysis in which the predictor variables are the different factors that make up the global dimension Personal adjustment of the BASC (percentiles) and the dependent variable is the dimensions of the adaptation of the Living Together at School Questionnaire for Students who evaluates the negative aspects of the category The student as an actor of antisocial and / or prosocial behavior

\begin{tabular}{llllll}
\hline & \multicolumn{4}{l}{$\begin{array}{l}\text { Unstandardized } \\
\text { coefficients }\end{array}$} & \multicolumn{2}{l}{$\begin{array}{l}\text { Standardized } \\
\text { coefficients }\end{array}$} \\
\cline { 2 - 6 } FACTORS $(P)^{2}$ & $\mathbf{B}$ & $\boldsymbol{E} \boldsymbol{r r}^{\mathbf{1}}$ & $\boldsymbol{\beta}$ & $\boldsymbol{t}$ & $\boldsymbol{p}$ \\
\hline (Constant) & 1.477 & .064 & & 23.027 & $.000^{* *}$ \\
Self-Esteem & -.002 & .001 & -.109 & -1.379 & .169 \\
Self-Confidence & -.002 & .001 & -.181 & -2.319 & $.021^{*}$ \\
Interpersonal & -.002 & .001 & -.120 & -1.539 & .126 \\
$\begin{array}{l}\text { Relations } \\
\text { Relationship with }\end{array}$ & -.001 & .001 & -.039 & -.484 & .629 \\
Parents & &
\end{tabular}

${ }^{1}$ Typ. Error.; ${ }^{1}$ Percentiles.; ${ }^{* *} p<.001 ;{ }^{*} p<.01$; Dependent variable: The student as an actor of antisocial behavior

Only the factor Self-Confidence predicts the negative behavior of the students $[t=-2.319 ; p<.05]$.

Moreover, Table 13 shows the results obtained after the implementation of the analysis of linear regression in which each of the dimensions of the BASC (percentiles) acted as predictors, and the dependent variable was the category Conflict resolution strategies on living together at school-positive. 
Table 13. Linear regression analysis in which the predictor variables are the global dimensions of the BASC (percentiles) and the dependent variable is the category of the adaptation of the Living Together at School Questionnaire for Students which evaluates the Conflict resolution strategies on living together at school-positive.

\begin{tabular}{llllll}
\hline & \multicolumn{2}{l}{$\begin{array}{l}\text { Unstandardized } \\
\text { coefficients }\end{array}$} & \multicolumn{4}{l}{$\begin{array}{l}\text { Standardized } \\
\text { coefficients }\end{array}$} \\
\cline { 2 - 6 } DIMENSIONS $(P)^{2}$ & $\mathbf{B}$ & $\boldsymbol{E r r}^{\mathbf{I}}$ & $\boldsymbol{\beta}$ & $\boldsymbol{t}$ & $\boldsymbol{p}$ \\
\hline (Constant) & 2.248 & .326 & & 6.895 & $.000^{* *}$ \\
Clinical & .001 & .005 & .016 & .112 & .911 \\
$\begin{array}{l}\text { Maladjustment } \\
\text { School }\end{array}$ & -.003 & .003 & -.086 & -.934 & .352 \\
$\begin{array}{l}\text { Maladjustment } \\
\text { Personal Adjustment }\end{array}$ & .010 & .004 & .258 & 2.682 & $.008^{*}$ \\
$\begin{array}{l}\text { Emotional } \\
\text { Symptoms Index }\end{array}$ & $6.61 \mathrm{E}-005$ & .006 & .002 & .011 & .991 \\
\hline
\end{tabular}

${ }^{1}$ Typ. Error.; ${ }^{1}$ Percentiles.; ${ }^{* *} p<.001 ;{ }^{*} p<.01$; Dependent variable: The student as an actor of antisocial behavior

The Personal adjustment dimension is defined as the only predictor of the category Positive coping strategies $[t=2.682 ; p$ $<.01]$.

Meanwhile, Table 14 shows the results obtained after the completion of the second linear regression analysis to determine which factor or factors of that dimension was responsible for this category.

Table 14. Linear regression analysis in which the predictor variables are the different factors that make up the global dimension Personal adjustment of the BASC (percentiles) and the dependent variable is the category of the adaptation of the Living Together at School Questionnaire for Students Conflict resolution strategies on living together at school-positive.

\begin{tabular}{llllll}
\hline & \multicolumn{4}{l}{$\begin{array}{l}\text { Unstandardized } \\
\text { coefficients }\end{array}$} & \multicolumn{2}{l}{$\begin{array}{l}\text { Standardized } \\
\text { coefficients }\end{array}$} \\
\cline { 2 - 6 } FACTORS $(P)^{2}$ & $\boldsymbol{B}$ & $\boldsymbol{E} \boldsymbol{r r}^{I}$ & $\boldsymbol{\beta}$ & $\boldsymbol{t}$ & $\boldsymbol{p}$ \\
\hline (Constant) & 1.881 & .159 & & 11.838 & $.000^{* *}$ \\
Self-Esteem & .004 & .003 & .097 & 1.200 & .232 \\
Self-Confidence & .006 & .003 & .182 & 2.265 & $.025^{*}$ \\
$\begin{array}{l}\text { Interpersonal } \\
\text { Relations }\end{array}$ & .004 & .003 & .120 & 1.515 & .132 \\
$\begin{array}{l}\text { Relations with } \\
\text { Parents }\end{array}$ & .000 & .003 & -.013 & -.162 & .872 \\
\hline
\end{tabular}

${ }^{1}$ Typ. Error.; ${ }^{1}$ Percentiles.; ${ }^{* *} p<.001 ;{ }^{*} p<.05$; Dependent variable: The student as an actor of antisocial behavior

As was the case above, the Self-Confidence factor becomes the variable that best predicts the category Conflict resolution strategies on living together at school-positive $[t=2.265 ; p$ $<.05]$.

In Table 15 we can see the linear regression analysis conducted to determine how the global dimensions of BASC affect the dimension that evaluates the negative aspects of the category Conflict resolution strategies on living together at school of the Living Together at School Questionnaire for Students.
Table 15. Linear regression analysis in which the predictor variables are the global dimension of the BASC (percentiles) and the dependent variable is the category Conflict resolution strategies on living together at school-negative of the adaptation of the Living Together at School Questionnaire for Students

\begin{tabular}{|c|c|c|c|c|c|}
\hline \multirow[b]{2}{*}{ DIMENSIONS $(P)^{2}$} & \multicolumn{2}{|c|}{$\begin{array}{l}\text { Unstandardized } \\
\text { coefficients }\end{array}$} & \multicolumn{2}{|c|}{$\begin{array}{l}\text { Standardized } \\
\text { coefficients }\end{array}$} & \multirow[b]{2}{*}{$p$} \\
\hline & B & $E r r^{I}$ & $\beta$ & $t$ & \\
\hline (Constant) & 1.106 & .235 & & 4.713 & $.000 * *$ \\
\hline $\begin{array}{l}\text { Clinical } \\
\text { Maladjustment }\end{array}$ & .004 & .003 & .149 & 1.072 & .285 \\
\hline $\begin{array}{l}\text { School } \\
\text { Maladjustment }\end{array}$ & .003 & .002 & .124 & 1.357 & .177 \\
\hline $\begin{array}{l}\text { Personal } \\
\text { Adjustment }\end{array}$ & .008 & .003 & .272 & 2.842 & $.005 *$ \\
\hline $\begin{array}{l}\text { Emotional } \\
\text { Symptoms Index }\end{array}$ & .003 & .004 & .094 & .716 & .475 \\
\hline
\end{tabular}

${ }^{1}$ Typ. Error.; ${ }^{1}$ Percentiles.; ${ }^{* *} p<.001 ;{ }^{*} p<.01$; Dependent variable: Conflict resolution strategies on living together at school-negative.

As can be seen above, the dimension Personal Adjustment is defined again as the variable that best predicts the category Conflict resolution strategies on living together at school, although in this case it refers to the dimension which evaluates the negative aspects of it $[t=2.842 ; p<.01]$.

In order to determine which factor or factors of that dimension were really responsible for this category, we proceeded to conduct a second linear regression analysis (see Table 16).

Table 16. Linear regression analysis in which the predictor variables are the different factors that make up the global dimension Personal adjustment of the BASC (percentiles) and the dependent variable is the category of the adaptation of the Living Together at School Questionnaire for Students which evaluates Conflict resolution strategies on living together at school-negative.

\begin{tabular}{llllll}
\hline & \multicolumn{2}{l}{$\begin{array}{l}\text { Unstandardized } \\
\text { coefficients }\end{array}$} & \multicolumn{2}{l}{$\begin{array}{l}\text { Standardized } \\
\text { coefficients }\end{array}$} \\
\cline { 2 - 6 } FACTORS $(P)^{2}$ & $\mathbf{B}$ & $\boldsymbol{E r r}{ }^{I}$ & $\boldsymbol{\beta}$ & $\boldsymbol{t}$ & $\boldsymbol{p}$ \\
\hline (Constant) & 1.657 & .119 & & 13.928 & $.000^{* *}$ \\
Self-Esteem & .003 & .002 & .111 & 1.359 & .176 \\
$\begin{array}{l}\text { Self-Confidence } \\
\text { Interpersonal }\end{array}$ & .000 & .002 & .006 & .078 & .938 \\
$\begin{array}{l}\text { Relations } \\
\text { Relationship with }\end{array}$ & -.001 & .002 & -.040 & -.491 & .624 \\
Parents & .004 & .002 & .159 & 1.925 & .056 \\
\hline
\end{tabular}

${ }^{1}$ Typ. Error.; ${ }^{1}$ Percentiles.; ${ }^{* *} p<.001$; Dependent variable: Conflict resolution strategies on living together at school-negative.

With marginal significance, the factor Relationship with parents was the best predictor of the category Conflict resolution strategies on living together at school-negative. $[t=1.925$; $p=.056]$.

\section{DISCUSSION}

The results obtained in the Behavior Assessment System for Children (BASC, 2004) are not clinically significant but are relatively high among the various participating students for each of the twelve factors that make up the assessment tool as well as the overall dimensions with a clinical nature which make up the BASC. It might be necessary, in this sense, to further analyze the demographic, contextual and/or situational characteristics of the participants because, as pointed out by several studies 
(Farrington, 2005; Melero, 2009; Patterson \& Yoerger, 2002), the onset of psychopathological symptoms is closely related to unfavorable social and family situations, poor services, birth rates above the average, low income, unemployment, etc.

Regarding the results obtained by adapting the Living Together at School Questionnaire for Students by Sánchez et al. (2009), we can conclude, on the one hand, that the majority of students perceived to have high social support among their peers in their daily lives at school. It also shows a certain predisposition to manifest mostly positive behavior rather than negative attitudes towards the materials and school facilities, as already demonstrated by Sánchez et al. (2009) in their research.

On the other hand, it should be emphasized, contrary to the results obtained in other studies (Calvo, 2003; Peralta, 2004), the higher frequency of positive behaviors on school life (eg. respecting the school timetable, teachers trating the students correctly, etc.) versus the presence of any other conduct of a negative nature (eg. breaking the rules, disrupting lessons, etc.).

Students also indicated that relationships and communication between them, as well as with teachers and with students from other cultures, was quite satisfactory, a result which matches the conclusions reached by Gotzens, Castelló, Genovard, and Badia (2003).

As for the perception of the student as a recipient of antisocial and/or prosocial behavior, the development of positive behavior predominates over the manifestation of negative conducts, regardless of whether they take place inside or outside school (Ortega \& Monks, 2005). When asked about the frequency with which they witness antisocial behaviour, either as actors or as observers, the rate of frequency of such conduct turns out to be low. They claim, however, that prosocial behavior is not very frequent either.

Regarding the type of strategies used by the students to deal with any conflict that occurs at school, it is striking to see the poor results for both the use of positive strategies (asking for help, showing assertiveness, etc.) and negative (not reacting, running away, etc.). This is detrimental to the state of school life and should become, therefore, an object of educational intervention.

Similarly, although many of the participating students have expressed, as discussed above, that they have a major source of social support among their colleagues in their daily lives in the centre, the results obtained suggest that neither their peers nor adults are are of great support when they have to solve their personal problems.

Contrary to the results obtained by Sanchez et al. (2009) in their research, the various participating students agree that the major ways of resolving school life conflicts involve methods which are more positive (eg, talking, giving advice, trying to find a solution all together, etc.) than negative (eg, with collective or individual punishment, calling parents, expulsions, etc..), an appreciation which seems to be consistent with the findings in other studies (Binaburo, 2007; Defensor del Pueblo, 2007; Díaz-Aguado, 2002; Trillo, 2006).

Depending on the results, we can also specify that most of the students who participated in this research claim they have received all the necessary information on the rules of school life, which they have worked in class, and that the teachers should be in charge of teaching such content as a subject or jointly by teachers and parents.

Regarding the results obtained in the linear regression analysis, it should be noted that except for the dimension that evaluates the negative aspects of the Living together at school situations category of the adapted version of the Living Together at School Questionnaire for Students, the variable that best explains the negative assessment that students make about the state of school life is the Clinical Maladjustment global dimension and, more specifically, the Atypicality factor within it. The remaining categories, more closely related to the objectives of this study, have been conditioned by the global dimension Personal Adjustment and, more specifically, by the SelfConfidence factor. Students with more self-confidence are the ones that tend to make more favorable assessments about the status of school life, participate less in conduct contrary to the school rules, have more skills conflict resolution skills of this nature, and vice versa. It also points, albeit timidly, to the importance of the Relationship with parents in conflict resolution strategies, which may be highlighting the important role of the family on the learning of positive conflict resolution strategies (Rodrigo, García, Máiquez, Rodríguez, \& Padrón, 2008).

We can therefore conclude that the teaching of social skills will contribute not only to the integral formation of students and, consequently, to their integral social and personal development, but also to the existence of an adequate school life (Campo et al., 2005; Creemers \& Reezigt, 1999; Delgado \& Contreras, 2008; Freiberg, 1999; Monjas, 1993, 2009; Seijo et al., 2005; Trianes, 1996). This has become one of the objectives of the current education curriculum, mainly as the education on interpersonal relationships from the earliest years of schooling has the advantage of preventing the development of problems that may occur at a later stage, at the end of primary education or during secondary education.

\section{REFERENCES}

Akiba, M. (2004). Nature and Correlates of Ijime: Bull\&ing in Japanese middle schools. International Journal of Educational Research, 41(3), 216-236. doi:10.1016/j.ijer.2005.07.002

Benbenishty, R., \& Astor, R. A. (2008). School Violence in an International Context. A Call for Global Collaboration in Research and Prevention. International Journal of Violence and School, 7, 5980.

Beck, S., \& Forehand, R. (1984). Social Skills training for children: a Methodological and clinical review of Behaviour modification studies. Behavioural Psychotherapy, 12, 17-45. doi: 10.1017/S0141347300009435

Binaburo, J. A. (2007). Educar desde el conflicto. Guía para la mediación escolar. Sevilla: Consejería de Educación de la Junta de Andalucía.

Caballo, V. E. (1993). Manual de evaluación \& entrenamiento de las habilidades sociales (1st ed.). Madrid: S. XXI.

Calvo, A. R. (2003). Problemas de convivencia en los centros educativos. Análisis e intervención. Madrid: EOS.

Campo, A., Fernández, A., \& Grisañela, J. (2005). La convivencia en los centros de secundaria. Un estudio de Casos. Revista Iberoamericana de Educación, 38, 121-145. Retrieved from http://www.rieoei.org/rie38a07.pdf

Carretero, A. (Coord.) (2008). Vivir convivir: convivencia intercultural en centros de educación primaria. Granada: Andalucía Acoge.

Consejo Escolar del Estado (2010). Informe sobre el estado y situación del sistema educativo. Curso 2007-2008. Madrid: Ministerio de educación. Retrieved from http://www.educacion.es/cesces/pg13.htm

Creemers, B. P. M., \& Reezigt, G. J. (1999). The role of school and classroom climate in Elementar\& School. In H. J., Freiberg (Ed.), School climate: Measuring, improving and sustaining health\& learning environments (pp. 30-48). London: Falmer Press.

Defensor del Pueblo (2007). Violencia escolar: el maltrato entre iguales en la ESO. Madrid: Oficina del Defensor del Pueblo.

Delgado, B., \& Contreras, A. (2008). Desarrollo social y emocional: desde los seis a los doce años. In B. Delgado (Coord.), Psicología del desarrollo: desde la infancia a la vejez (pp. 35-66). Madrid: McGraw-Hill. 
Díaz-Aguado, M. J. (2002). Convivencia escolar y prevención de la violencia. Madrid: Centro Nacional de Educación y Comunicación Educativa.

Díaz-Aguado, M. J. (2005). La violencia entre iguales en la adolescencia y su prevención desde la escuela. Psicothema, 17(4), 549-558. Retrieved from http://www.psicothema.com/psicothema.asp?id=3144

Domingo, J. (2008). El aprendizaje cooperativo. Cuadernos de Trabajo Social, 21, 231-246. Retrieved from http://dialnet.unirioja.es/servlet/articulo? codigo $=2756952 \&$ orden $=23$ 3819\&info=link

Farrington, D. (2005). Childhood origins of Antisocial Behavior. Clinical Psychology \& Psychotherapy, 12(3), 177-190. doi: 10.1002/cpp.448

Fernández, F. D., Pichardo, M. C., \& Arco, J. L. (2005). Diseño, aplicación y evaluación de un programa piloto para la prevención del maltrato entre compañeros. Revista Mexicana de Psicología, 22(2), 375-384.

Freiberg, J. H. (1999). School climate: Measuring, improving and sustaining healthy learning environments. London: Falmer Press.

Furlong, M. J., Greif, J. L., Bates, M. P., Whipple, A. D., Jiménez, T. C., \& Morrison, R., (2005). Development of the California School Climate and Safety Survey-Short Form. Psychology in the Schools, 42(2), 137-149. doi: 10.1002/pits.20053

Goldstein, A. P., Sprafkin, R. P., Gershaw, N. J., \& Klein, P. (1989). Habilidades sociales y autocontrol en la adolescencia. Barcelona: Martínez Roca.

González, J., Fernández, S., Pérez, E., \& Santamaría, P. (2004). Adaptación española del sistema de evaluación de la conducta en niños y adolescentes: BASC. Madrid: TEA Ediciones.

Gotzens, C., Castelló, A., Genovard, C., \& Badía, M. (2003). Percepciones de profesores \& alumnos de E.S.O. sobre la disciplina en la escuela. Psicothema, 15(3), 362-368. Retrieved from http://www.psicothema.com/pdf/1073.pdf

Gresham, F. M. (1988). Social skills: conceptual and applied aspects of assessment, training and social validation. In J. C. Witt, S. N. Elliot \& F. M. Gresham (Eds.), Handbook of Behavior Therapy in Education (pp. 523-546). New York: Plenum Press.

Herrera, L., Defior, S., \& Lorenzo, O. (2007). Intervención educativa en conciencia fonológica en niños prelectores de lengua materna española y tamazight. Comparación de dos programas de entrenamiento. Infancia y Aprendizaje, 30(1), 39-54.

Herrera, L., Ortiz, M. M., \& Sánchez, S. (2010). La convivencia escolar en Educación Primaria y Secundaria. Conductas positivas y negativas. In R. Roig \& M. Fiorucci (Eds.), Claves para la investigación en innovación y calidad educativas. La integración de las Tecnologías de la Información y la Comunicación y la Interculturalidad en las aulas (pp. 221-233). Alicante: Marfil.

Hirchstein, M. K., Edstrom, L. V., Frey, K. S., Snell, J. L., \& McKenzie, E. P. (2007). Walking the Talk in Bullying Prevention: Teacher Implentation Variables Related on Initial Impact of the Steps to Respect Program. School Psychology Review, 36(1), 3-21. Retrieved from

http://www.nasponline.org/publications/spr/pdf/spr361hirschstein.pd f

Instituto Nacional de Estadística (2010). Anuario Estadístico de España 2010. Madrid: INE. Retrieved from http://www.ine.es

Jares, X. R. (2006). Pedagogía de la convivencia. Barcelona: Graó.

Johnson, D., Johnson, R., \& Smith, K. (1998). Active learning: cooperation in the college classroom. Edina, Minnesota: Interaction Book Company.

Laureano, L. (2002) (Coord.). Las acciones estructurales comunitarias en España y sus comunidades autónomas - Período 2000-2006. Madrid: Comisión Europea. Representación en España.

Ley Orgánica 2/2006, de 3 de mayo, de Educación. BOE n.106, 4 de mayo de 2006

López-Guzmán, T. J., González, V., Herrera, L., \& Lorenzo, O. (2007). Melilla: Ciudad fronteriza internacional e intercontinental. Análisis histórico, económico y educativo. Frontera Norte, 37(19), 7-33. Retrieved from http://redalyc.uaemex.mx/src/inicio/ArtPdfRed.jsp?iCve=13603701

Mayoral, J. F. (2005). El mosaico de Melilla. En J. L. López (Coord.) Experiencias interculturales en Melilla (pp. 23-40). Granada: Universidad de Granada, Sindicato Autónomo de Trabajadores de la Enseñanza.

Melero, J. M. (2009). Conflictividad escolar y la nueva profesión docente. Málaga: Ediciones Aljibe.
Michelson, L., Sugai, D. P., Wood, R. P., \& Kazdin, A. E. (1987). Las habilidades sociales en la infancia: evaluación y tratamiento. Barcelona: Martínez Roca.

Monjas, M. I. (1993). Programa de Enseñanza de Habilidades de Interacción Social para niños y niñas en edad escolar (PHEIS). Salamanca: Trilce.

Monjas, M. I. (2009). Cómo promover la convivencia. Programa de asertividad y habilidades sociales (PAHS). Madrid: CEPE.

Monjas, M. I., \& González, B. (Dirs.) (2000). Las habilidades sociales en el currículo. Madrid: Secretaría General Técnica del Ministerio de Educación.

Ortega, R. (2007). La convivencia: un regalo de la cultura a la escuela. Revista Idea La Mancha, 4, 50-54.

Ortega, R., \& Del Rey, R. (2004). Construir la convivencia. Barcelona: Edebé.

Ortega, R., \& Monks, C. (2005). Agresividad injustificada entre preescolares. Psicothema, 17(3), 453-458. Retrieved from http://www.psicothema.com/psicothema.asp?id=3128

Patterson, G. R., \& Yoerger, K. (2002). A developmental model for early- and late-onset delinquency. En J. Reid, G. Patterson \& J. Snyder (Eds.), Antisocial behavior in children and adolescents: a developmental anal\&sis and model for intervention (pp. 147-172). Washington, DC: American Psychological Association. doi: 10.1037/10468-007

Peralta, F. J. (2004). Estudio de los problemas de convivencia escolar en estudiantes de enseñanza secundaria. (Doctoral Thesis). Retrieved from http://www.biblioteca.uma.es/bbldoc/tesisuma/16789222.pdf

Ramírez, S., \& Justicia, F. (2006). El maltrato entre escolares y otras conductas-problema para la convivencia. Revista Electrónica de Investigación Psicoeducativa, 4(2), 265-290. Retrieved from http://investigacionpsicopedagogica.org/revista/new/ContadorArticulo.php?139

Reynolds, C. R., \& Kamphaus, R. W. (1992). BASC: Behavior Assessment System for Children : manual. Circle Pines, MN: American Guidance Service.

Rodrigo, M. J., García, M., Máiquez, M. L., Rodríguez, B., \& Padrón, I. (2008). Estrategias y metas en la resolución de conflictos cotidianos entre adolescentes, padres y madres. Infancia y Aprendizaje, 31(3), 347-362.

Rodríguez, C., Herrera, L., Lorenzo, O., \& Álvarez, J. (2008). El valor familia en estudiantes universitarios de España: análisis y clasificación. Enseñanza e Investigación en Psicología, 13(2), 215230. Retrieved from http://redalyc.uaemex.mx/pdf/292/29213202.pdf

Sánchez, S., Mesa, M. C. Seijo, D., Alemany, I, Rojas, G., Ortiz, M. M., ... Fernández, A. M. (2009). Convivencia Escolar y Diversidad Cultural. Estudio sobre la convivencia escolar en centros educativos de Melilla. Madrid: Secretaría General Técnica del Ministerio de Educación.

Seijo, D., Novo, M., Arce, R., Fariña, F., \& Mesa, M. C. (2005) Prevención de comportamientos disruptivos en contextos escolares: programa de intervención basado en el entrenamiento de habilidades sociocognitivas (Programa EHSCO): guía de actividades para Educación Primaria. Granada: Grupo editorial universitario.

Smith, P. K. (Ed.) (2003). Violence in Schools: The Response in Europe. London: RoutledgeFalmer.

Tilmatine, M., El Molghy, A., Castellanos, C., \& Banhakeia., H. (1998). La lengua rifeña Tutlayt Tarifit. Comunidad Autónoma de Melilla: Servicio de Publicaciones.

Trianes, M. V. (1996). Educación y competencia social: un programa en el aula. Málaga: Aljibe.

Trillo, J. (2006). Violencia escolar entre iguales: Informe del Defensor del Pueblo. In Ministerio de Educación, La convivencia en las aulas: problemas y soluciones. Madrid: Secretaría General Técnica del Ministerio de Educación.

UNESCO (2004). Global education digest 2004. Montreal: UNESCO Institute for Statistics. Retrieved from http://www.unesco.org/education/docs/EN_GD2004_v2.pdf

Vázquez, M. J., Fariña, F., \& Seijo, D. (2003). Teorías explicativas del comportamiento agresivo y antisocial desde una perspectiva neurofisio-biológica. In F. Fariña \& R. Arce (Eds.), Avances en torno al comportamiento antisocial, evaluación y tratamiento (pp. 17-38). Madrid: Ministerio de Trabajo y Asuntos Sociales.

Verdugo, M. A. (1997). Programa de Habilidades Sociales: PHS. Salamanca: Amarú. 